\title{
Tosprogede vej- og byskilte i Sønderjylland
}

\section{En kommenteret citatmosaik fra debatten i de sønderjyske medier 2007-2008}

\section{af H.E.SøRENSEN}

Fra sommeren 2007 til foråret 2008 bølgede debatten om tosproget skiltning i Sønderjylland og Sydslesvig frem og tilbage i grænselandet. Anledningen var et forslag stillet af den tyske mindretalsorganisation BDN. Debatten gav et godt overblik over standpunkterne i identitetsdebatten i grænselandet. Samtidig gav den et fingerpeg om de udfordringer, som både mindretal og flertal på begge sider af grænsen står over for i en tid, hvor det ikke er tilstrækkeligt at være tolerant over for andre kulturer, men hvor det også forventes, at man skilter med det. Grænselandskronikør H.E. Sørensen giver her et kommenteret sammendrag af debatten.

I efteråret 2006 afløste gårdejer Hinrich Jürgensen, Tinglev, dyrlæge Hans Heinrich Hansen fra Hejsager som formand for det tyske mindretals hovedorganisation Bund Deutscher Nordschleswiger (BDN). I sin »jomfrutale« på BDN's delegeretmøde i april 2007 på Hansens Hotel i Tinglev genoptog Jürgensen det forslag, som forgængeren havde fremsat nogle år forinden, om dobbeltsprogede by- og vejskilte i Sønderjylland - dog uden nærmere at præcisere, i hvilket omfang han forestillede sig en sådan skiltning.

$\mathrm{Nu}$ er tosprogede skilte som sådan ikke noget særsyn rundt omkring i verden, hvor de nogle steder er opsat af praktiske, andre steder af symbolske grunde. I Jugoslavien brugte man allerede $i$ 1960 'erne skilte med begge landets alfabeter - det latinske og det kyrilliske - i egne, hvor det kyrilliske alfabet var herskende, så også kroater, slovenere og andre »analfabeter «, herunder turister, kunne finde vej. Det var noget rent praktisk. Det er det også, når man på vejskilte i Grækenland skriver navnet med latinske bogstaver under de græske. Eller når man i Israel ud over skiltning på landets to sprog hebræisk og arabisk også bringer stednavnene på engelsk. En lignende service, altså engelsksprogede skilte, findes også i andre lande med 
egne alfabeter som Indien og en række arabiske stater. Ellers ville vi andre jo ikke have en jordisk chance for at finde rundt!

Men det var næppe det, Hinrich Jürgensen havde i tankerne, da han stillede sit forslag. Alle i Sønderjylland og Sydslesvig kan flertalssproget. Det er ikke på grund af læsevanskeligheder eller ukendskab til egnens geografi, at mindretallet ønsker skiltning på sit eget sprog.

Derfor kan det måske have en smule interesse at se, hvad man gør andre steder, hvor man er i den samme eller en lignende situation.

\section{Skilte i Europa}

I Sydtyrol har man i mange år - $\mathrm{i}$ hvert fald siden 1960'erne - brugt skilte med både italienske og tyske navne, f.eks. Bolzano/Bosen og Vipetino/Sterzing. Dette er måske ikke så mærkeligt, al den stund det tysksprogede "mindretal " $\mathrm{i}$ store dele af området rent faktisk udgør flertallet af befolkningen. Det samme er tilfældet $i-i$ hvert fald dele af - Baskerlandet (Euskadi) i Nordspanien. Her har man i 1990'erne indført brugen af begge sprog (spansk og baskisk) på vejskilte, bl.a. ved afkørslerne fra Nordmotorvejen. I Siebenbürgen/Transsylvanien i Rumænien, hvor der findes et stort tysk mindretal, angives bynavnene mange steder på begge sprog (Somberek/Schomberg eller Hermannstadt/Sibiu - i det sidste tilfælde er der da en forskel, der er til at tage og føle på). I Belgien ser man skilte på landets to sprog, fransk og flamsk (Bruges/Brügge; Bruxelles/Brüssel). Og i Wales er der byskilte på walisisk, også selv om dagligsproget de fleste steder er engelsk. Det gamle lokalsprog overlever i stednavnene, som man også kender det $\mathrm{i}$ andre yderområder som Bretagne og Lapland.

I Finland/Suomi er der en relativt lille svensktalende befolkning, som stædigt holder fast ved sit sprog. Det udgør omtrent 6 procent af befolkningen eller omkring 300.000 mennesker, der hovedsageligt bor på Ålandsøerne og i kystegnene. Bortset fra Ålandsøerne er der kun få og små områder, hvor svensk er dominerende. Närpes, som i øvrigt er Tønders venskabsby, er vistnok den eneste fastlandskommune med svensk flertal. Men begge sprogene er ligeberettigede overalt, hvor mindretallet (det være sig svensk eller finsk) udgør 8 procent eller mindst 3000 mennesker. Selv om der er under 8 procent svensktalende i Helsingfors/Helsinki og Åbo/Turku, er svensk alligevel et ligeberettiget sprog, fordi mindretallet udgør mere end 3000 personer. 
Der skal således være skiltning på både svensk og finsk $\mathrm{i}$ de to store byer, ligesom begge sprog skal kunne bruges i forvaltningen. Kun på Ålandsøerne, hvor 98 procent er svensktalende, er dette sprog enerådende, som finsk er det $i$ mere end 90 procent af fastlandet.

Mens man i de nordligste egne af Norge, Sverige og Finland (Lapland) flere steder skilter med stednavne på flere sprog (det nationale hovedsprog plus f.eks. samisk), har man i Frankrig den politik, at kun den franske navnemåde må anvendes på vej- og byskilte, også i egne med traditionelle lokale sprog, som i Bretagne, Baskerlandet og Provence. I Alsace (Elsass) er navnene af historiske grunde tyske - ofte med en gang fransk fernis. Her anvendes dog kun de franske navneformer, også selv om de kan virke let komiske som f.eks. de to berømte seværdigheder Château de Haut Koenigsbourg (Königsburg) og Musée d'Unter den Linden i Colmar - eller passet Col de la Schlucht. Ren sprogforbistring!

Selv om vi ikke har tosprogede by- og vejskilte i Sønderjylland, henvises der adskillige steder til tyske institutioner på tysk. Og det er da kun rimeligt, at der står "Deutsches Museum «, "Zentralbücherei « eller "Deutsche Schule", for det hedder "stederne" nu engang, lige så vel, som der bør skiltes med f.eks. "Dansk Skole“ eller "Dansk Børnehave" syd for grænsen. Det er også naturligt, når der vises til "Niebüll« (og ikke Nibøl) ved rundkørslerne omkring Tønder, ligesom der flere steder er skilte mod »Flensburg «. Det er det mest praktiske, da det er de tyske navne, der står på de vejkort, bilisterne skal køre efter. På samme måde, som der burde stå »Tønder « og »Aabenraa« syd for grænsen. Og nogle steder gør det.

\section{Bemærkelsesværdig tavshed}

I de første dage efter det tyske møde på Hansens Hotel i Tinglev var der bemærkelsesværdigt tavst om Jürgensens forslag. Kun Aabenraas borgmester Tove Larsen ytrede sig. Det var et "spændende forslag", sagde hun forsigtigt, men tilføjede samtidig, at »kommunen er stor, der skal mange skilte til, og det vil koste mange penge.« Senere blev hun mere tydelig i sin stillingtagen. Til Jyllands-Posten sagde hun (iflg. Der Nordschleswiger, 23/6-07): »Vor by hedder Aabenraa, og det ved tyskerne også. Alt andet ville være et falsk signal. " Haderslevs borgmester Hans Peter Geil afviste brugen af tysksprogede skilte i sin kommune, mens Sønderborgs borgmester Jan Prokopek Jensen ikke 
ønskede at tage stilling, og borgmesteren i Tønder, Vagn Therkel Petersen, var tavs om sagen. Forslaget blev således ikke mødt med jublende applaus fra lokalt officielt hold.

Ellers var der ro om spørgsmålet, selv om man nok kunne have forventet en vis reaktion. Det virkede nærmest, som om ingen havde bemærket det. Eller at man gik som katten om den varme grød.

Flensborg Avis skrev dog (5/5-07), at det var »livsbekræftende«, at den nye formand for det tyske mindretal »tænkte nyt «, selv om det aktuelle forslag vel næppe kunne kaldes helt nyt. »Om tiden er moden til Hinrich Jürgensens forslag - på det folkelige niveau i Sønderjylland - vil givetvis hurtigt vise sig," skrev Flensborg Avis.

Og det gjorde det da også.

Allerede to dage senere kom det frrste indlæg $\mathrm{i}$ debatten $\mathrm{i}$ form af en leder i JydskeVestkysten (7/5-07), hvor redaktør Poul Erik Thomsen undrede sig over, at Jürgensens udtalelse var »blevet mødt med noget, der kunne minde om tavshed. Eller måske er der i virkeligheden tale om ligegyldighed, " spurgte Thomsen. Han så forslaget dels som et udslag af, at Jürgensen som ny formand havde brug for en sag til at markere sig med, dels som et forsøg på at tydeliggøre det tyske indslag i den sønderjyske hverdag. Dette fandt han meget rimeligt og naturligt, "for der kan også gå for meget lighed og broderskab i forholdet mellem dansk og tysk i grænselandet. Der er endda grund til at råbe et stort hurra for den lille forskel.«

Men det aktuelle forslag fandt Poul Erik Thomsen dog overflødigt: "Tiden er ganske enkelt løbet fra det forslag som grænselandssag i forhold til flertal og mindretal, " skrev han. "Ingen blandt de tyskorienterede har i dag problemer med at finde rundt i Sønderjylland alene ud fra de dansksprogede skilte. " Men tosprogede skilte kunne måske "sende et signal til det øvrige Europa: Sådan ser et velfungerende og harmonisk grænseland, der bygger på gensidig respekt, ud, « sluttede Thomsen, der også mente, at det kunne være en service for turister.

Det sidste er nok mere end tvivlsomt. Hvad skulle den stakkels udlænding gøre, der kørte efter »Aabenraa « på kortet, når skiltet viste til "Apenrade«?

Thomsens artikel var måske den gnist, der skulle til for at sætte fut i tønderet. I hvert fald blussede debatten voldsomt op i de næste uger og måneder. 


\section{Debatten kommer i gang}

Mens det tyske mindretal og avisen Der Nordschleswiger naturligt nok bakkede formanden op, var meningerne delte på dansk side. Tilhængerne, som var langt de færreste blandt dem, der ytrede sig, mente, at det - 87 år efter Genforeningen - måtte være på tide, at vi viste hinanden det hensyn at bruge begge sprog. Blandt de ivrigste fortalere var overinspektør Peter Dragsbo fra Museum Sønderjylland Sønderborg Slot. Han havde tidligere luftet ideen i kronikker i såvel Flensborg Avis som JydskeVestkysten, uden at det havde haft den store effekt. Nu skrev han i Der Nordschleswiger (6/6-07), at tosprogede skilte burde indføres, ikke af praktiske grunde, men fordi »dansk og tysk på skiltene skal være et signal for flertalsnationens respekt for, at der findes et mindretal med egen sproglig og national identitet. Og det skal være et signal om, at vi er modne til at anerkende, at vi har et grænseland med flere nationale tilhørsforhold, sprog og kulturstrømme.«

Peter Dragsbo fik følgeskab af Flensborg Avis' lederskribent Raning Krueger, som 25/6-07 mente, at modstanden viste, at der var "for lavt til loftet“ i Danmark. Når de danske sydslesvigere havde været tilbageholdne med at stille forslag om tosproget skiltning, skete det "af hensyn til det danske flertal i Sønderjylland, der ikke var modent til en tosproget skiltning nord for grænsen. Desværre viser det sig, at danskerne fortsat ikke er modne," skrev Krueger.

Dette blev imødegået af Gert Ries, Sønder Løgum, som forudså, at man måtte »regne med, at der vil opstå en del tysk irritation over dansk skiltning. Det vil det danske mindretal få at føle. Jeg tvivler lidt på tyskernes større "modenhed ", men en succes er det jo at have fået lov" til at opsætte skilte med både dansk og tysk tekst syd for grænsen (Flensborg Avis, 29/6-07).

Og historikeren Axel Johnsen, Gråsten, stillede spørgsmåltegn ved »loftshøjden på Flensborg Avis« (Flensborg Avis, 3/7-07) og fortsatte: "Hvis Flensborg Avis mener, at den dobbeltsprogede skiltning skal ses som en venlig gestus over for den nationale modpart, hvorfor er avisen så ikke for længst gået over til at skrive Kupfermühle/Kobbermølle i stedet for blot Kobbermølle, Eckernförde/Egernførde i stedet for blot Egernførde. Og Schafflund/Skovlund i stedet for Skovlund?« Trods flere læserbreve om det samme spørgsmål fik han ikke noget egentligt svar fra avisens redaktion. 


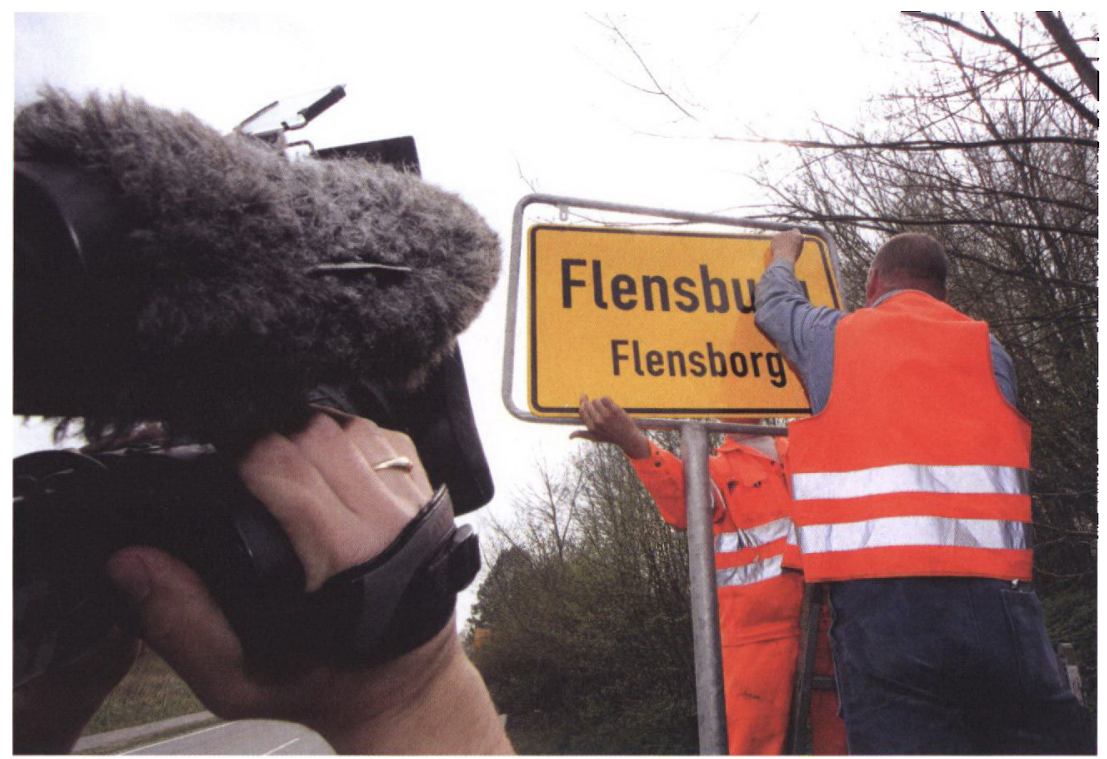

Midt under debatten om skiltene $i$ granselandet opsatte Flensborg by det forste af $i$ alt 60 bebudede tosprogede skilte ved byens indfaldsveje. Det skete den 24 . april 2008 ved Oksevejen. Ved en lille ceremoni begrundede Flensborgs overborgmester Klaus Tscheuschner byraidets beslutning (ifolge Flensborg Avis): "De tosprogede skilte er en anerkendelse af byens omskiftelige historie og dens to kulturer, men de er ogsa et synligt tegn pai, at Flensborg opfatter sig selw som den dansk-tyske grænseregions hemmelige hovedstad". Foto: Flensborg Avis / Sebastian Iwersen.

Der Nordschleswiger har allerede i stor udstrækning indført en sådan dobbeltsproget navngivning, måske fordi ikke alle ved, at Scherriff er det samme som Skarrev, eller at Rønshoved hedder Randersacker på hjemmetysk.

Jyllands-Posten meldte sig klart på modstandernes side med en leder (31/5-07), hvis overskift "En dum idé» ikke lod nogen i tvivl om avisens holdning. Efter at have henvist til 1864, 1. Verdenskrig og besættelsestiden samt nævnt nutidens samarbejde og fredelige sameksistens, fortsatte lederskribenten: »Især hos den ældre del af befolkningen lurer imidlertid minderne om herrefolket lige under overfladen, og derfor er det rigtigt dumt af Bund Deutscher Nordschleswiger at fremprovokere nogle unødvendige modsætningsforhold. [...] Den idé fortjener en stille død«. Bemærk: Avisen skrev »herrefolk« uden anførselstegn! Det var altså ikke blot en ironisk betegnelse. 
En del læserbreve i danske aviser, ikke mindst JydskeVestkysten, viste, at Jyllands-Posten ikke stod alene. Der var stor modstand, og argumenterne var ikke altid lige saglige.

"I Danmark har vi altså kun ét officielt sprog, og det er dansk, også i Sønderjylland, "skrev formanden for Dansk Folkeparti i Aabenraa, René Dupont (JydskeVestkysten, 4/5-07), hvilket ikke kan bestrides. Partifællen Søren Krarup, der er valgt til Folketinget i Sønderjylland, var enig: "Danske byskilte skal være på dansk. Det byder respekten for det hjemmehørende flertal “ (Der Nordschleswiger, 23/6-07).

Partiets byrådsmedlem i Aabenraa, Ejler Schütt, Løjt Kirkeby, »troede først, at der var tale om en majkatspøg, " som »hurtigt kunne skydes ned, " men "i et interview $i$ avisen $i$ søndags afslører Hinrich Jürgensen, at det skam er alvorligt ment " (JydskeVestkysten, 10/5-07). Samtidig glædede han sig over, at der ikke stod "Messersberg" ved Knivsbjerg, men havde i skyndingen åbenbart overset, at det netop er et af de få steder i Sønderjylland, hvor der allerede er dobbeltsproget skiltning: Knivsbjerg/Jugendhof Knivsberg.

Den kendte debattør, fhv. chefredaktør Karsten Madsen, var lidt i strid med sig selv om, hvad han skulle mene. I et temmelig langt indlæg i Flensborg Avis (14/5-07) prøvede han at se sagen fra begge sider, men endte dog med at støtte forslaget. Sønderjylland er jo ikke alene i verden, skrev han, og tosproget skiltning findes mange steder, også i områder, hvor der havde været blodige konflikter mellem to folkegrupper også længe efter 2. Verdenskrig. "Når man kan læse tyske vejskilte i det franske Strassbourg, hvor hagekorsflaget for 70 år siden vejede fra byens berømte domkirke, må det også være muligt at praktisere dette stykke 'symbolik' i Sønderjylland, "skrev Karsten Madsen. Hans stavemåde af bynavnet er i sig selv en slags to-sprogethed eller "sproglig forbrødring «: Byen hedder på tysk Strassburg og på fransk Strasbourg. Endelig håber jeg, at flaget ikke vejede (alt for meget?), men vajede!

Forhenværende amtsrådsmedlem Mads Schmidt Eriksen (Venstre), Broballe ved Nordborg, fandt forslaget "pjattet og nedladende« og mente, det hørte hjemme i $Æ$ Rummelpot, ligesom han i det hele opfattede det som en provokation, når der stod tyske skilte med henvisning til bl.a. »Kindergarten " ud for danske familiers huse (JydskeVestkysten, 16/5-07).

Samme dag skrev Niels H. Hansen, Ronshoved, at det kunne blive "sjovt med alle de sprog, man kunne forudse på danske vejskilte [...] 
af hensyn til de mange indvandrere: arabisk, albansk, irakisk, somalisk og alle de andre. "Men i øvrigt fandt han, at "mageløst pjatteri til selvhævdelse skal man godt nok lede længe efter, " og uanset mindretallets »tilsyneladende mangel på beskæftigelse kunne man godt ønske, at de fandt ud af, hvor de havde valgt at bosætte sig« (JydskeVestkysten, 16/5-07).

Jan Kannegaard, Løgumkloster, foreslog, at »hvis de tysksindede i Danmark og de dansksindede $\mathrm{i}$ Tyskland er så vilde med naboens kultur, er der masser af muligheder for, at man flyttede efter den kultur, som åbenbart betyder så meget for en " (JydskeVestkysten, 20/ 5-07).

Gunnar Kvisgaard Knudsen, Tinglev, fandt forslaget »tåbeligt« og foreslog, at man i tolerancens navn også opstillede vej- og byskilte på sønderjysk (JydskeVestkysten, 24/5-07). Sådanne findes dog allerede visse steder, f.eks. ved " $E$ Markmandssti« i Ballum.

Ivar Rasmussen, Sønderborg, mente, at turisterne nok skulle finde vej uden tosprogede skilte, ligesom grænsependlere, der »er veluddannede mennesker, ellers har vi ikke brug for dem," også kunne klare sig uden (JydskeVestkysten, 24/5-07).

Regionsrådsmedlem for Dansk Folkeparti Jytte Lauridsen, Aabenraa: »Det er desværre, når der går politik i den naturlige del af hverdagen, den mindre hyggelige del af tysk mentalitet viser tænder og kommer op til overfladen " (JydskeVestkysten, 5/6-07).

Frede Warming, Sommersted: "Jeg troede naivt på, at vi nu havde en fælles fjende $i$ islamismen. Men som jeg opfatter det, har Hinrich Jürgensen sammen med muslimerne påtaget sig offerrollen « (JydskeVestkysten, 20/6-07).

Byrådsmedlem Lars Rydhard (Dansk Folkeparti), Aabenraa, mente, at "skiltet [d.v.s. "Zentralbücherei«] foran det tyske bibliotek i Vestergade forekommer inderligt overflødigt. Den store bygning dominerer hele gadebilledet, så man slet ikke ser vejskiltet. Og jeg tvivler på, om det nogensinde har hjulpet tyske trafikanter til at finde vej« (JydskeVestkysten, 10/7-07).

Derimod anbefalede folketingsmedlem Bente Dahl (Radikale) fra Løgumkloster »de fire store sønderjyske kommuner at gøre som Flensborg by, nemlig at lade deres byskilte fremover have både tysk og dansk formulerede vejnavne, " og at man lod det "være op til kommunerne at bestemme, om de vil have både tyske og danske navne på byskiltene« (JydskeVestkysten, 13/7-07). Her var altså ikke alene tale 
om selve bynavnet, men med navnene på de enkelte gader og veje $\mathrm{i}$ de fire sønderjyske kommuner, d.v.s. i hele Sønderjylland. Dette er dog nok at drive sin tolerance for vidt. Og det er $i$ hvert fald langt ud over Hinrich Jürgensens oprindelige forslag.

Andrea Kunsemüller, der er leder af Regionskontoret for Region Sønderjylland-Schleswig i Padborg, så det som et tegn på stolerance og åbenhed«, at det nu var tilladt med tosproget skiltning syd for grænsen. "At vise mangfoldigheden frem giver et positivt signal og er spændende - også for dem, der besøger landsdelen som turister, erhvervsdrivende, mennesker på vej. Burde det samme ikke gælde på den danske side? Hvad er der at tabe? Jeg mener, at der kun er noget at vinde ved at have tosprogede skilte. I hvert fald i de fire købstæder i Sønderjylland/Nordslesvig “ (Flensborg Avis, 11/7-07).

Gerhardt Busse, Aabenraa, skrev, at »flere skilte forvirrer nu en gang mere, end de gavner, om det så er på dansk, tysk, frisisk eller tyrkisk, « og påpegede, at »i denne besynderlige skiltedebat glemmes ét mindretal, nemlig de ordblinde. Flere skilte på flere sprog vil kun forvirre disse mennesker. Alt til fare for trafiksikkerheden « (JydskeVestkysten, 17/7-07).

Mag.art. et cand.mag. Orla Christensen, Aabenraa, angreb, at det tyske mindretal var blevet kaldt "indvandrere" og "dårligt integrerede«, og kaldte en sådan betegnelse for både arrogant og uforskammet, »i betragtning af, at det tyske har haft hjemstavn i Sønderjylland siden slutningen af det 14 . og begyndelsen af det 15 . århundrede.« Han fortsatte: "De har, og det kan ikke understreges tydeligt nok, mindst lige så megen ret til og rod i den sønderjyske muld som vi dansksindede, og i al fald langt mere end mange 'kongerigske' tilflyttere" (JydskeVestkysten, 19/7-07).

\section{De historieløses brigade}

Den gamle stridsmand Bjørn Svensson var klart imod forslaget, som han mente udsendte wet dårligt signal. Nu 87 år efter Genforeningen forbedres forholdet mellem flertal og mindretal dag for dag i hverdagens stilfærdige forløb. Derimod går det galt hver gang, man med krampagtige anstrengelser gør forsøg på at forcere udviklingen. $\mathrm{Og}$ det krampagtige afsløres allerede, når Hinrich Jürgensen formanende peger på, at der er gået 87 år siden Genforeningen, " mente Bjørn Svensson. 
Han fortsatte: »Det tyske mindretal ved jo kun alt for godt af smertelig selvoplevelse, at efter 1920 har vi oplevet en tysk besættelse fra 19401945 med overfald trods ikke-angrebspagt, med terror, mord og kz-lejre med oplevelser, som har ramt mange endnu levende. Det er rigtigt, at mange ikke længere vil føle sig generet af tyske vejskilte nord for grænsen, men det afgørende er, at hos mange andre vil det vække følelser til live, som skader hverdagens rolige forsoningsudvikling.

Det er ikke alene på tysk side, man er så historieløse. Hvert år demonstrerer tysk militær på Dybbøl den 18. april, at bagmændene for denne misforståede forsoningsgestus, den gamle Sønderborgborgmester A.P. Hansen og oberstløjtnant J.P. Rasmussen, var fuldt bevidste om, at de trampede på følelserne hos mange gamle sønderjyder, da de tog dette initiativ. Nu er Hinrich Jürgensen gået til de historieløses brigade, « sluttede Svensson (JydskeVestkysten, 4/6-07).

Flere deltagere i debatten hævdede, at mens næsten alle stednavne i Sydslesvig var af dansk oprindelse og i mange tilfælde (delvist) forvanskede i deres tyske form (Skovlund/Schafflund, Lyshøj/Lützhöft, Fjolde/Viöl), så er de tyske stednavne nord for grænsen alle kunstprodukter fra tiden efter 1864. Dette blev klart afvist af Jürgen Reinemer, Sønderborg, som ud fra gamle kort (fra 1600-tallet) påviste, at adskillige stednavne på Als og Sundeved havde tyske former allerede for 3-400 år siden (JydskeVestkysten, 27/6-07). At kortene viser tysksprogede stednavne netop i den periode kan måske skyldes, at hertughofferne, som vel havde bestilt kortene, var (plat)tysksprogede. Denne formodning styrkes af, at de fleste sogne på Als og Sundeved i middelalderen havde klart dansksprogede navne - om end ofte skrevet med nærmest lydskriftagtig stavning.

I samme forbindelse påpegede historikeren René Rasmussen, Tønder, at enkelte danske stednavne i Sønderjylland rent faktisk var udgået fra tyske former. Således hed Gråsten oprindeligt Grawenstein, skrev han. I følge Trap skrives det i 1640'erne "Grawestein « eller "Growstein «, men efter slotsbyggeriet i 1690'erne blev den almindeligt anvendte form Gravenstein (altså med tysk "V ", der som bekendt udtales som "f (). Dette navn havde således ikke noget med grå (eller grove) sten at gøre, men med en greve (Frederik Ahlefeldt, som ejede godset). Om navnet oprindeligt har med geologi at gøre er i øvrigt yderst tvivlsomt. "Steen « (sten/stein) er et gammelt hollandsk/ flamsk ord for borg eller slot - sml. borgen Steen i Antwerpen og Gravensteen nær fæstningsbyen Naarden øst for Amsterdam. Formen 
kendes også på dansk $\mathrm{i}$ herregården Ryssensteen syd for Lemvig samt i forterne Kongensteen og Prindsensteen på Guldkysten (Ghana) i Afrika og fæstningen Fredriksten ved Halden i Norge. Den danske udtale af Gravenstein (altså med "v« og ikke »f «) har så gennem årene ændret sig til Gråsten - og byen har således mere eller mindre fået sit oprindelige navn tilbage.

René Rasmussen fortsatte: »Fra 1920 til 1945 havde det tyske mindretal en grænserevision som målsætning. De tyske stednavne blev af den danske flertalsbefolkning opfattet som et meget synligt udtryk for truslen mod grænsen. Efter 1945 eksisterer denne trussel ikke mere, og der er ikke længere grund til at nære modvilje mod de tyske stednavne. Forholdet mellem danske og tysksindede i grænselandet har siden 1955 udviklet sig i meget positiv retning, og jeg kan da personligt glæde mig over skilte, der viser vej til 'Deutsche Schule'," skrev René Rasmussen.

Han fortsatte: "Men jeg kan ikke tilbageholde den kætterske tanke, at en af årsagerne til det gode forhold $\mathrm{i}$ grænselandet er de to nationale mindretals forholdsvise usynlighed. Det er nemmere at leve med et nationalt mindretal, hvis man ikke hele tiden får stukket dets eksistens i næsen. I andre europæiske grænseregioner opstår der mange konflikter, når tosprogede byskilte bliver overmalet, og det vil utvivlsomt også ske i Sønderjylland.

Men er det nu i grunden et rimeligt krav at stille til et nationalt mindretal med århundredgamle rødder, at det skal være usynligt for det gode naboskabs skyld? Det er egentlig dette, diskussionen drejer sig om. Jeg er selv i tvivl!« (JydskeVestkysten, 20/6-07).

Der Nordschleswiger skrev i en leder 9/6-07, at "komisk nok - men sandt - kan i vor medieverden en myg pludselig blive til en elefant. Når man kørte frem med f.eks. Gross Jündewatt som paradeeksempel, [som det var sket i Danmarks Radio til skræk og advarsel, forf.] gør det $\mathrm{i}$ realiteten enhver saglig diskussion i pressen umulig. [...] Er betegnelser som Apenrade, Tondern, Hadersleben og Sonderburg historisk set en forbrydelse? Vrøvl, på samme måde som man i sammenligning med hans forgænger vil gøre ham [Jürgensen] til en fanatiker af den hårde skole." Om tyske henvisningsskilte og lignende "må man føre en konstruktiv dialog med den fornuftige danske side, altså med de nordslesvigske kommuner. Alt andet er ulagte æg. Mindretallet må dog også selvkritisk i egne rammer finde ud af, hvad det egentlig er, man vil, « skrev Der Nordschleswiger. 


\section{BDN stiller et konkret forslag}

Samme dag (9/6-07) blev den sidste måneds debat kommenteret af redaktør Poul Erik Thomsen i JydskeVestkystens leder. Normalt hører forholdet mellem mindretal og flertal under rubrikken "fredelig sameksistens «, skrev han og pointerede, at et vist mål af forskel er nødvendig: "I samme øjeblik forskellene er væk, er mindretallene nemlig også blot et fortidsminde, « og derfor er det formanden for mindretallets pligt »at pudse den tyske facade i Sønderjylland [...] hvis ikke han skal blive den sidste formand for et tysk mindretal.« Om selve debatten og ikke mindst tonen i debatten skrev Thomsen: »Han [Hinrich Jürgensen] har allerede opdaget, at han ikke alene har overtaget formandsposten $\mathbf{i}$ mindretallet, han har også sat sig på det, der kan være øretævernes holdeplads. For en ting er at være uenig. Det er i orden at være modstander af tysksprogede byskilte i Danmark. Problemet er nogle af de voldsomme udfald, der er blevet rettet mod Hinrich Jürgensen, og hvor der i hvert fald hverken er tale om fred eller fordragelighed. Men nu rolig, det er jo ikke en krigserklæring, han er kommet med. Blot et forslag, der fortjener en god debat. Ud fra gensidig respekt.«

Og Der Nordschleswigers chefredaktør Siegfried Matlok fandt hele balladen noget overdreven. "Der findes vigtigere ting for mindretallet end at strides om skilte med et skarpt afvisende dansk flertal. [...] Danskerne er nu en gang meget nationale, " fortsatte han, "så lad os sætte det på vågeblus« (23/6-07).

Hinrich Jürgensen svarede sine mange kritikere dels gennem flere stort set enslydende læserbreve, dels gennem sin tale på Bund Deutscher Nordschleswigers hovedbestyrelsesmøde den 25. juni 2007, hvor han bl.a. sagde: "Begrundelsen for forslaget om de tosprogede byskilte er at gøre det synligt, at der findes to kulturer i Nordslesvig, nemlig den danske flertalsbefolkning og et - særdeles godt integreret - tysk mindretal. Dette er noget, som adskiller Nordslesvig fra det øvrige Danmark, og som Nordslesvig kan markedsføre sig med på positiv måde.

Derudover drejer det sig om skridtvis at forbedre det tyske sprogs og tysk kulturs betydning i det offentlige rum, som det også blev foreslået af indenrigs- og sundhedsminister Lars Løkke Rasmussen i en skrivelse til de sønderjyske kommuner og Region Syddanmark i juni 2006. Det følger også Europarådets ekspertkommissions udtalelse om, at "tysk er ikke et fremmedsprog i Nordslesvig." 
Han opsummerede derefter sit forslag i fem punkter: »1. Tosprogede byskilte ved de fire købstæder. 2 . Tosprogede byskilte, hvor der findes tyske institutioner (børnehaver, skoler og/eller biblioteker). 3 . Henvisningsskilte til tyske institutioner, hvor sådanne skilte endnu ikke findes. 4. Tyske henvisningsskilte til servicefunktioner som rådhuse, sygehuse og politistationer. 5. Oplysning om sprogkendskab (tysk og engelsk) hos medarbejdere i den kommunale forvaltning.«

Lars Løkke Rasmussen havde i det ovennæunte brev (af 9/6-2006) skrevet, at »muligheden for at tale tysk - også ved kontakt med de offentlige myndigheder - er af betydning for såvel de tyske statsborgere, der arbejder på den danske side af grænsen, som for det tyske mindretal i Sønderjylland. Jeg vil derfor opfordre til, at det i forbindelse med overvejelserne omkring den fremtidige borgerbetjening også drøftes, hvordan kommunalreformen kan bruges som afsæt for tiltag, som i højere grad tilgodeser disse personers ønske om at anvende tysk. Der er blandt de ansatte $i$ de sonderjyske kommuner et stort potentiale for at tale tysk, som vil være oplagt at udnytte i denne forbindelse. Det kunne i den forbindelse f.eks. overvejes at tillade, at dokumenter, herunder f.eks. mindretalsskolernes vedtægter, $\mathrm{i}$ højere grad end i dag kan fremlægges på tysk.

Endvidere kunne det overvejes at henlede opmærksomheden på, hvilke medarbejdere i den kommunale administration, der taler andre sprog end dansk, herunder tysk. Dette kunne ske ved skiltning, f.eks. ved indgangen til rådhuset, ved de pågældende medarbejderes kontorer eller ved serviceskranken. Det kunne også overvejes at lade det fremgå af kommunens hjemmeside, at der er mulighed for at tale andre sprog end dansk i forbindelse med henvendelse til kommunen.

Et andet område, som kan nævnes i denne sammenhæng, er plejehjemsområdet, idet behovet for at tale tysk ofte stiger med alderen blandt medlemmerne af det tyske mindretal. Det kan derfor overvejes i højere grad at efterkomme eventuelle ønsker om at tale tysk med plejepersonalet, såfremt der er mulighed herfor.

Disse forslag er ment som inspiration, således at de muligheder, som kommunalreformen fører med sig, også udnyttes i relation til borgerbetjeningen af det tyske mindretal. Dette vil efter min opfattelse bl.a. bidrage til at fremme en fortsat positiv udvikling af den gode ånd, der er mellem det tyske mindretal og det danske flertal i grænselandet.« 


\section{Hinrich Jürgensen trækker forslaget tilbage}

Efter næsten et års debat kastede Hinrich Jürgensen håndklædet $\mathrm{i}$ ringen. På Bund Deutscher Nordschleswigers delegeretmøde 23/42008 trak han forslaget om tosprogede skilte tilbage. "Jeg har måttet erkende, at tiden ikke er moden for tosprogede skilte«, sagde han og meddelte, at »nu vil Bund Deutscher Nordschleswiger koncentrere sig om at få skilte på tysk, der viser til mindretallets børnehaver, skoler og andre institutioner« (JydskeVestkysten, 27/4-08).

Denne beslutning gav anledning til et par kommentarer. Således sagde chefredaktør Siegfried Matlok til JydskeVestkysten (27/4-08): "Jeg har sagt, at tiden ikke er moden, men jeg synes nok, at man bør fastholde sit ønske om at få tosprogede byskilte ved de store byer $\mathrm{i}$ Senderjylland en dag - jeg understreger en dag - fordi jeg håber på, at den politik, som man nu har vedtaget i Flensborg - i øvrigt med det danske mindretals stemmer - har en signalvirkning. Det vil på langt sigt have en afsmittende effekt nord for grænsen. Men giv ro og giv tid. [...] Det gavner ikke en udvikling med vold og magt at gennemføre noget, som vil føre til tilbageskridt. Så det må laves med et godt dansk ord: 'Fingerspitzengefühl', " sluttede han (JydskeVestkysten, 27/4-08). Man kan næsten se det skæve smil!

Dagen efter (JydskeVestkysten, 28/4-08) havde Poul Erik Thomsen endnu en leder om sagen: „Danske byer skal ikke også skrives med i en tysk udgave på grund af et tysk mindretal nord for grænsen. Det forslag kom ganske enkelt for sent. [...] Hvis der skal være dobbeltsprogede skilte i Sønderjylland, skal det ikke alene være af hensyn til et mindretal, men i givet fald bygge på, at det er det, både flertal og mindretal vil for dermed at vise en landsdel med en særlig national dobbelthed.«

\section{Tosproget skiltning vedtages syd for grænsen}

Samtidig med den heftige debat nord for grænsen vedtog Landdagen i Kiel, naturligvis støttet af det danske mindretals parti Sydslesvigsk Vælgerforenings to mandater, at der kunne opsættes tosprogede skilte i Sydslesvig som en gestus over for de danske og frisiske mindretal. De findes i øvrigt allerede i Nordfrisland, hvor der flere steder er skilte både på tysk og frisisk, f.eks. Bredstedt/Bräist.

I Flensborg Avis (19/6-07) skrev historikeren Gerret Liebing Schlaber 
fra Studieafdelingen på Dansk Centralbibliotek i Flensborg en kronik, hvor han stillede spørgsmålet: "Hvad skal egentlig være meningen med flersprogede vejskilte? «: - »For det meste argumenterer man med deres symbolske betydning," svarede han sig selv og fortsatte: "Jeg synes, at der er mange flere gode grunde til, at det danske mindretal nu bør benytte lejligheden til at gå ind for tosprogede vej- og byskilte. Et af mindretallets storste problemer er, at det ikke er særlig synligt i hverdagen. De danske institutioner og de mange danske aktiviteter berører næppe flertalsbefolkningens hverdag. Jeg har alt for ofte oplevet, at både herboende tyskere og danskere nordfra slet ikke er klar over, at der findes en danskhed syd for grænsen. Efter min opfattelse er det simpelthen et helt naturligt udtryk for ligeberettigelse mellem flertal og mindretal, at også mindretallets sprog bliver synligt i gadebilledet. På den måde er det lettere for flertalsbefolkningen at se, at mindretallene virkelig er en berigelse for landsdelen og ikke bare en luksusforanstaltning for en afgrænset gruppe personer, der jamrer på højt niveau, når de ikke får endnu flere tilskud fra de offentlige kasser.«

Han sluttede med dette konkrete forslag: "Jeg vil foreslå, at man begynder med dansk-tyske "pilotprojekter " på udvalgte steder, hvor mindretallet har en særlig stor betydning, eller hvor der kommer mange turister, f.eks. Flensborgs og Tønders historiske bykerner, Harreslev og Bov eller Sønder Løgum og Ubjerg. Såfremt den danske side ikke vil være med i første omgang, bør man ikke vente syd for grænsen med at søsætte projektet. Når det først har etableret sig et sted, vil andre snart efterligne det - sådan er det ofte med fornyelser, der tidligere har været omstridt. Derimod vil det være helt forkert at knytte opstillingen sammen med modydelser fra den anden side af grænsen. [...] Måske lige bortset fra pilotprojekterne, der burde få finansiel støtte ovenfra for hurtigt at komme på scenen, kan opstillingen af de nye skilte forbindes med rutineskifter, der i forvejen er nødvendige nu og da, " skrev Gerret Liebing Schlaber.

Han fortsatte: "Man kan altid sige, at der findes vigtigere problemer. Men når man aldrig tager det første skridt, kommer man ikke videre. Vi har stadig mange opgaver at løse i det dansk-tyske grænseland. Flersproget skiltning kunne forenkle losningen på mange af dem - ikke mindst på kerneproblemet 'grænsen i hovederne'.«

Men heller ikke i Sydslesvig var man enige om, at det er en god idé. Nogle dage senere skrev Lothar Zilch fra Slesvig i et læserbrev: 
"Forvaltningssproget hos os er tysk; færdselsskilte, byskilte og lignende er ikke undtaget herfra. Det har altid været muligt for danskere at finde rundt $i$ vort land, sproglige problemer eller barrierer eksisterer ikke" (Flensborg Avis, 4/7-07).

Også Peter Huber fra Brackel advarede (Flensborg Avis, 17/7-07) mod at fare for hastigt frem. Man ville derved "give enhver lille landsbybølle mulighed for at markere sig med pensel og farve, « skrev han. "Idioter og neonazister får etableret en sceneplads med uforsvarlig stor offentlig opmærksomhed. Kan mindretallet være tjent med det? « Vel kun, hvis man »absolut vil indtage en kunstig offerrolle," besvarede han sit eget spørgsmål og fortsatte: »Hvis de danske bynavne nu virkelig er en hjertesag for SSV, ville det være meget mere fornuftigt, at Vælgerforeningen i sine gennemgående tyske publikationer fremtidig konsekvent holder op med at skrive Kopenhagen, når Danmarks hovedstad er ment. Tyskerne har jo aldrig forbudt at skrive København, « sluttede Peter Huber maliciøst.

Ved mindehøjtideligheden for Istedslaget 1850 på Flensborg Gamle Kirkegård den 25. juli 2007 sagde Flensborg Avis' chefredaktør Bjarne Lønborg, at de tosprogede skilte var "et spørgsmål om at fastholde og udvikle den gensidige respekt og agtelse for hinanden $i$ to forskellige kulturer." Han henviste til et eksempel fra Ultental i Sydtyrol, hvor $98 \%$ af beboerne er tysktalende. Desuagtet havde man by- og vejskilte på både tysk og italiensk. Respekten for den anden kultur og nationalitet var således ikke afhængig af procenter, sagde han og fortsatte: »Og selv, hvis de to procent italienere flyttede fra området, ville man opretholde den tosprogede skiltning (Flensborg Avis, 27/7-07).

Måske ikke så mærkeligt, al den stund Ultental ligger i Italien, hvor det officielle sprog er italiensk, og rejsende fra andre dele af landet vel også skal have mulighed for at bruge deres eget sprog i deres eget land. Det havde været ulig mere interessant at få at vide, om man også ville opretholde den tysksprogede skiltning, hvis der var tale om et rent italiensksproget område. Så kunne man da tale om respekt for et nationalt mindretal!

Formanden for Sydslesvigsk Vælgerforening, Flemming Meyer, tog sagen helt roligt. Den flersprogede skiltning er ikke af "essentiel betydning for det danske mindretal, " sagde han, for "jeg tror ikke, at det danske mindretals identitet er afhængig af tosproget skiltning « (Flensborg Avis, 3/5-07).

Han har selvfølgelig ret. 
Men lige så selvfølgeligt stemte SSVs landdagsmedlemmer for at gøre tosprogede skilte lovlige, da spørgsmålet blev behandlet og vedtaget i Landdagen 13. juni 2007. Alt andet ville have været tåbeligt, for ikke at sige selvmorderisk. Selv om Poul Erik Thomsen fandt den danske holdning en smule "dobbeltmoralsk " (JydskeVestkysten, 28/408), så kan det næppe forpligte myndighederne nord for grænsen, hvad man vedtager i det slesvigholstenske delstatsparlament. Og forøvrigt: Kunne man forestille sig, at Slesvigsk Parti stemte nej til tosproget skiltning i Sønderjylland?

Dagen efter vedtagelsen i Landdagen hilste Flensborg Avis (14/6-07) beslutningen velkommen $i$ en leder under overskriften "Flerkulturel harmoni«. Her skrev Bjarne Lonborg, at "det er glædeligt, at SSV i Flensborg reagerer hurtigt ved at foreslå tosprogede byskilte allerede fra næste år, « altså fra 2008. Bjarne Lønborg fortsatte: »Vi mener i øvrigt ikke, at der nu er grund til at være tilbageholdende med ønsket om flersproget skiltning i danske kredse i Sydslesvig af hensyn til hidtidige formodninger om, at der eventuelt kunne opstå følelsesbetonet dansk modstand mod tysksprogede skilte i Sønderjylland.«

Og det danske landdagsmedlem Anke Spoorendonk udtalte til Flensborg Avis (26/7-08), at »beslutningen om at indføre tosprogede skilte i Flensborg er et af de største mindretalspolitiske fremskridt i de seneste årtier.«

23. april 2008 blev så det første dobbeltsprogede byskilt sat op på Oksevejen ved Flensborgs bygrænse. I den anledning sagde Anke Spoorendonk til JydskeVestkysten (27/4-08), at "med de tosprogede byskilte tager vi hul på en ny æra i grænselandet.«

\section{Forskelle i debatkultur og historieopfattelse}

Som forklaring på den hidsige - om end næppe afklarende - debat nord for grænsen og den langt mere stilfærdige meningsudveksling i Sydslesvig skrev Gerret Liebing Schlaber i Grenzfriedenshefte (2007, nr. 4): »Man må huske på, at debatkulturen i Danmark er anderledes end i Tyskland. Således trykker danske aviser praktisk taget alle modtagne læserbreve, også den slags, som tyske redaktioner straks ville smide i papirkurven. Derfor får ekstreme meninger og værtshusvrøvl, der mere er forsøg på at markere sig selv frem for at formidle mådeholdne synspunkter, uforholdsmæssig stor plads og opmærksomhed. Særligt betænkeligt er det, at vigtige medier i Danmark, hvor ytrings- 
friheden spiller en overordentlig stor rolle, gennem deres usaglige fremstilling er med til at skabe en ophidset stemning og på den måde i høj grad hindrer en for et demokratisk samfund nødvendig saglig diskussion.«

Selv om Schlaber måske finder ytringsfriheden i Danmark lovlig høj, og usaglige læserbreves betydning vel næppe helt kan afvises, skønt man heller ikke skal overdrive deres indflydelse, da selv danske læsere er i stand til at skille skidt fra kanel, så er det tænkeligt, at Siegfried Matlok kom sandheden nærmere, da han sagde til JydskeVestkysten (27/4-08), at "2. Verdenskrig kaster stadig skygger, og det er grunden til, at debatten om tosprogede byskilte har været ophedet i Danmark, mens den stort set ikke har været der i Tyskland."

Det er vist ikke forkert at sige, at Tyskland spiller en langt større rolle $\mathrm{i}$ danskernes bevidsthed, end Danmark gør for den almene tysker. Tyskland er vor største og i øvrigt eneste landfaste nabo, men Tyskland har grænse til adskillige lande, hvoraf Danmark langt fra er det største eller det, der for tyskerne spiller den væsentligste rolle. Men med et århundredes historie (1848-1945) in mente ligger »frygten for Tyskland « mange danskere i blodet, hvor absurd det end - rationelt set - kan forekomme i dag, hvor vi er gode naboer og allierede, mens modsat en tilsvarende følelse $\mathbf{i}$ Tyskland over for den nordlige nabo næppe eksisterer uden for ganske snævre kredse.

Selv om mange af os læser og taler tysk og gerne rejser i Tyskland, er dette sikkert den dybere baggrund for den nærmest instinktmæssige modvilje, der næsten pr. automatik griber en stor del af os mod selv en rent symbolsk indrømmelse, som de tosprogede vej- og byskilte jo ret beset er.

Men er Matloks udtalelse ikke også en karakteristik af hjemmetyskernes syn på danskerne? Er forslaget om at indføre tosprogede skilte uden praktisk betydning ikke i virkeligheden et symptom på det mindreværdskompleks, som et meget lille mindretal næsten pr. naturlov må føle over for et talmæssigt stærkt dominerende flertal? Noget sådant er i hvert fald ikke ukendt $\mathrm{i}$ verdenshistorien.

Når det er sagt er der måske plads til et par kendsgerninger. Det tyske mindretal udgør maksimalt 10.-15.000 personer ud af en samlet befolkning i Sønderjylland på ca. 250.000 . Ved det sidste amtsrådsvalg fik Slesvigsk Parti 4420 stemmer, eller 2,7\%, hvilket betød, at mindretallets parti kun blev repræsenteret $\mathrm{i}$ amtsrådet takket være valgforbund med Kristendemokraterne. Bortset fra den gamle Tinglev Kom- 
mune er der næppe noget sted i Sønderjylland, hvor mindretallet overstiger $10 \%$ af befolkningen. I den nuværende Aabenraa Kommune fik partiet ved seneste kommunevalg 5,9\% af stemmerne og to mandater. I de tre øvrige kommuner var andelen af stemmer betydeligt lavere. I Tønder rakte stemmerne til et mandat, i Sønderborg til et halvt og i Haderslev til et kvart, hvilket betyder henholdsvis cirka 4,2 og $1 \%$ af stemmerne.

Spørgsmålet er derfor, om det er rimeligt at indføre tosproget skiltning af hensyn til en så marginal befolkningsdel, som oven i købet for en stor dels vedkommende har dansk/sønderjysk hjemmesprog, og som (i hvert fald for manges vedkommende) udtrykker sig bedre på dansk end på tysk.

Mindretallet har naturligvis sin fulde ret til at betjene sig af sit tyske sprog internt - i skole og kirke, foreninger og presse - ligesom det vil være rimeligt, om der blev opsat skilte på tysk, der henviser til tyske institutioner. Men derfra og til at indføre tysksprogede by- og færdselsskilte (for slet ikke at tale om gadenavne!), er der et langt spring, og det kan næppe være rimeligt over for flertalsbefolkningen, der jo dog udgør over $95 \%$, ligesom der ikke kan være megen ræson i at øge forvirringen, hverken for os selv eller landsdelens gæster, ved helt overflødigt - at opsætte skilte på to sprog. 